\title{
Eksistensi Lembaga Mediasi Sebagai Sarana Penyelesaian Sengketa Medis
}

\author{
Evalina Alissa ${ }^{1}$, Sasmiar $^{2}$ \\ ${ }^{1,2}$ Fakultas Hukum Universitas Jambi, Indonesia \\ Jl.Raya Jambi-Ma.Bulian, Km.15, Mendalo Indah, Kecamatan Jambi Luar Kota, Indonesia \\ Correspondence email: evalina_alissa@unja.ac.id, email: sasmiar@unja.ac.id
}

\begin{abstract}
Abstrak. Artikel ini membahas mengenai eksistensi oleh lembaga mediasi sebagai sebuah sarana penyelesaian didalam sengketa, yang mana membahas mengenai dasar hukum dan kedudukan dari lembaga mediasi, kriteria atau sengketa medis dan juga kekuatan hukum dari lembaga mediasi didalam penyelesaian sengketa medis. Metode penelitian yang digunakan oleh penulis adalah metode penelitian doktrinal yang mana dimaksud untuk menemukan suatu prinsip hukum, aturan hukum dan juga doktrin hukum demi mendapatkan jawaban terhadap isu hukum didalam pembahasan yang ada didalam artikel ini. Sengketa medis timbul dikarenakan terjadinya penafsiran yang berbeda antara pelayanan kesehatan dan keluarga pasien/pasien didalam melakukan pelayanan terhadap kesehatan. Namun didalam undang-undang praktek kedokteran menyebutkan bahwa terhadap penyelesaian sengketa medis dapat dilakukan penyelesaian melalui jalur litigasi dan melakukan pengaduan kepada Majelis Kehormatan Disiplin Kedokteran Indonesia dan semenjak disahkannya undang-undang kesehatan serta undang-undang rumah sakit lembaga mediasi mulai diakui sebagai sebuah lembaga yang melakukan proses penyelesaian diluar lembaga peradilan dan memiliki kekuatan hukum dari lembaga mediasi tersebut.
\end{abstract}

Kata Kunci: Lembaga Mediasi; Sengketa Medis; Litigasi.

\begin{abstract}
This article discusses the existence of mediation institutions as a means of resolution in disputes, which discusses the legal basis and position of the mediation institution, the criteria or medical disputes and also the legal power of the mediating institution in the resolution of medical disputes. The research method used by the author is a doctrinal research method which is intended to find a legal principle, rule of law and legal doctrine in order to get answers to legal issues in the discussion in this article. Medical disputes arise due to different interpretations between health services and the patient/ patient's family in providing services to health. However, in the medical practice law, it is stated that the settlement of medical disputes can be done through litigation and submitting complaints to the Honorary Council of Indonesian Medical Disciplines and since the health law and the hospital law, mediation institutions have begun to be recognized as an institution that conducts medical work. the settlement process outside the judiciary and has the legal power of the mediation institution.
\end{abstract}

Keywords: Mediation Institution; Medical Disputes; Litigation.

\section{PENDAHULUAN}

Penyelesaian sengketa merupakan sebuah penyelesaian sebuah perkara yang dilakuan antara satu pihak dengan pihak yang lainnya, serta didalam penyelesaiannya ini dapat dilakukan melalui dua jalur, yaitu non litigasi dan litigasi. Perihal penyelenggaraan kesehatan merupakan sebuah program prioritas pemerintah yang memberikan hak katas kesehatan sebagai sebuah konsep dari hak asasi manusia (HAM) yang mana hal ini merupakan hak mutlak yang harus dipenuhi oleh pemerintah pusat maupun pemerintah daerah. John Lock mengatakan bahwa perlindungan terhadap hak secara kodrat merupakan sebuah basis didalam pendirian sebuah negara yang memberikan sebuah kontrol sosial untuk dapat melindungi hak dasar ${ }^{1}$ yang harus dipenuhi didalam masyarakat. Maka dapat kita pahami bahwa unsur dari kesehatan merupakan sebuah hak dasar yang harus dimikiki oleh manusia didalam melaksanakan kehidupan dan perlindungan kesehatan yang harus dipenuhi oleh negara.

Konstitusi Negara Republik Indonesia dalam Pasal 28H ayat (1) pada intinya menyebutkan bahwa setiap manusia memiliki hak untuk kehidupan yang sejahtera secara lahir dan bathin serta sudah pasti berhak untuk memperoleh pelayanan terhadap kesehatan dan hal ini dipertegas dengan terbitnya undang-undang tentang kesehatan. ${ }^{2}$ Maka dalam konsep the right of healty care mengariskan bahwa hal ini merupakan hak dasar yang menjadi kewajiban oleh negara untuk dipenuhi, yang mana pada tataran HAM terhadap kesehatan setiap warga negara berhak serta wajib untuk mendapatkan pelayanan kesehatan dalam sebuah pelayanan dan derajat yang optimal maka berkaitan dengan hal tersebut peningkatan didalam ppeningkatan sebuah derajat dari kesehatan harus selalu diupayakan dan dilaksanakan sebaik mungkin.

Berkaitan dengan pelayanan kesehatan ini selalu mengalami perubahan pola mengenai interaksi penyediaan jasa didalam kesehatan dan juga dengan orang yang menerima jasa dari kesehatan tersebut, serta yang harus dipahami bahwa dalam hal ini pasien bukan saja sebagai orang yang sakit dan memerlukan pertolongan dari seorang dokter

${ }^{1}$ Titon Slamaet Kurnia, Hak-Hak Atas Derajat Kesehatan Optimalisasi Sebagai HAM di Indonesia, Alumni, Bandung, 2007, hlm. 67.

${ }^{2}$ Undang-Undang Nomor 36 Tahun 2009 Tentang Kesehatan. 
maupun perawat yang melakukan sebuah proses didalam sebuah pelayanan dari perawatan. Maka konteks pelayanan didalam kesehatan ini merujuk pada Undang-Undang Pelayanan Publik ${ }^{3}$ yang mana undang-undang ini mengattur mengenai prinsip pelayanan yang dilakukan oleh pemerintah agar baik dan lebih efektif.

Meskipun didalam prakteknya masih banyak mengalami kendala didalam pelayanan kesehatan seperti kurangnya rasa sadar dan juga pemahaman hukum terkait dengan hal kesehatan yang mana dapat menimbulkan sengketa medis didalam pelaksanaannya. Namun yang tak kalah penting adalah terkait dengan perlindungan terhadap hak dari seorang pasien dan juga hak yang dimiliki oleh seorang tenaga kesehatan. Maka dalam hal ini hak pasien didalam pelayanan kesehatan sudah disebutkan secara jelas berkaitan dengan hak pasien, yaitu mendapatkan informasi yang jelas terhadap sebuah tindakan pelayanan medis, dapat meminta lebih dari satu pendapat dokter, mendaptkan sebuah pelayanan yang sesuai dengan kebutuhan medis serta pasien dapat menolak tindakan medis yang dilakukan oleh dokter serta mendapatkan isi rekaman medis yang sudah dilakukan. ${ }^{4}$ Serta sudah di atur pula secara khusus didalam Pasal 32 Undang-Undang Tentang Rumah Sakit ${ }^{5}$ mengenai hak pasien tersebut.

Apabila terjadi sebuah pelanggaran terhadap hak pasien tersebut maka pasien dapat mengajukan sebuah gugatan sebagaimana yang terdapat didalam Pasal 45 Undang-Undang Penyelesaian Konsumen ${ }^{6}$, dan melakukan laporan kepada pihak kepolisian maupun penyidik lainnya yang berkaitan dengan penerapan sanksi pidana terhadap pelanggaran kepada hak-hak dari seorang pasien. Hal ini lah yang berujung kepada terjadinya sebuah tuntutan serta adanya sebuah gugatan didalam perkara hukum. Tuntutan ini biasanya berawal dari terdapatnya keganjilan pada sebuah tindakan pasca menjalani sebuah pengobatan yang terkadang timbul dikarenakan jeleknya komunikasi yang dibangun oleh pihak terkait berkaitan dengan pelayanan kesehatan antara dokter kepada pasien maupun rumah sakit kepada pasien sebagai penyelenggara dari healtg provider kepada health receivers.

Pada sebuah praktek kedokteran apabila terjadi sebuah sengketa maka dapat diselesaikan dengan cara-cara seperti perdamaian sebuah sengketa, melalui jalur litigasi dan melalui sebuah pengaduan permasalahan kepada Mejelis Kehormatan Disiplin Kedoteran Indonesia (MKDKI) sesuai dengan ketentuan yang terdapat didalam Pasal 66 Undang-Undang Praktek Kedokteran. MKDKI meruapakan sebuah lembaga yang mana memiliki sebuah wewenang yang berkaitan dengan menentukan sebuah tindakan/kesalahan yang mana dilakukan oleh seorang dokter maupun dokter gigi pada penerapan disiplin ilmu kedoteran dan dokter gigi serta menetapkan sebuah sanksi ${ }^{7}$ terhadap pelanggaran tersebut. Namun yang banyak dilakukan terhadap sengketa ini adalah melalui cara litigasi sebagai sebuah cara didalam menyelesaikan sebuah perkara medis dengan pihak rumah sakit maupun dokter. Pada cara litigasi ini harus melalui tata cara pembuktian yang pastinya akan memakan waktu yang lama dan biaya yang tidak sedikit pula, serta pihak pasien pun harus menyadari bahwa akan adanya resiko sebaliknya berupa tuntutan balik dari pihak rumah sakit maupun dokter yang digugat.

Maka cara yang cukup efektif adalah melalui cara mediasi didalam penyelesaian sengketa terhadap resiko medis yang terjadi, sebab resiko yang timbul cukup ringan bagi pihak yang bersengketa, konsep mediasi ini kemudian berkembang dengan nama penyelesaian sengketa di luar pengadilan ataupun yang lazim disebut degan alternative dispute resolution. Penggunaan lembaga mediasi di Indonesia telah diatur didalam Undang-Undang Nomor 39 Tahun 1999 Tentang Arbitrase dan Alternatif Penyelesaian Sengketa (Undang-Undang AAPS), yang mana termasuk didalam Alternatif Penyelesaian Sengketa (APS) seperti negoisasi mediasi, konsultasi serta adanya penilaian ahli. Keberadaan lembaga mediasi didalam Undang-Undang Kesehatan tersebut sudah pasti merujuk kepada Undang-Undang AAPS.

Maka artkel ilmiah ini akan membahas mengenai kedudukan lembaga mediasi sengketa medis, kriterian maupun ruang lingkup dari sengketa medis serta apa saja yang dapat diselesaikan oleh lembaga mediasi dan mengenai kekuatan hukum terhadap keputusan yang dikeluarkan oleh lembaga mediasi.

\section{METODE}

Metode penelitian yang digunakan adalah metode penelitian doktrinal ataupun yang lazim disebut dengan metode penelitian normatif. Metode penelitian ini dipilih dikarenakan penelitian ini bersifat preskriptif, yang mana ilmu hukum sama-sama kita pahami sebagai sebauah aturan yang merujuk kepada tujuan dari hukum yang pastinya nenjunjung sebuah nilai keadilan, terdapat konsep hukum dan juga norma-norma hukum ${ }^{8}$ yang terkandung didalam sebuah aturan dan tujuan dari pemberlakuan sebuah aturan didalam masyarakat. Maka sumber data yang diperoleh didalam artikel ilmiah ini adalah bersumber dari undang-undang, maupun peraturan hukum yang berlaku dan adanya doktrin-doktrin yang terkait dengan penelitian yang dilakukan.

\footnotetext{
${ }^{3}$ Undang-Undang Nomor 25 Tahun 2009 Tentang Pelayanan Publik.

${ }^{4}$ Pasal 52 Undang-Undang Nomor 29 Tahun 2004 Tentang Kedokteran.

${ }^{5}$ Undang-Undang Nomor 44 Tahun 2009 Tentang Rumah Sakit.

${ }^{6}$ Undang-Undang Nomor 8 Tahun 1999 Tentang Perlindungan Konsumen.

7 Pasal 1 ayat (2) Peraturan Menteri Kesehatan Republik Indonesia Nomor 150/MENKES/PER/I/2011 Tentang
} Keanggotaan Majelis Kehormatan Disiplin kedoteran Indonesia.

${ }^{8}$ Soerjono Soekamto, Pengantar Penelitian Hukum, Universitas Indonesia, Jakarta, 2006, hlm. 6. 


\section{HASIL DAN PEMBAHASAN}

\section{Kedudukan Lembaga Mediasi di Dalam Penyelesaian Sengketa}

Mediasai merupakan sebuah prosedur sebagai penengah yang mana seseorang bertindak sebagai sebuah kendaraan untuk dapat melakukan alur berkomunik yang bersengketa, ${ }^{9}$ yang mana para pihak yang bersengketa ini sudah pasti memiliki pandangan yang berbeda atas terjadinya sengketa tersebut, serta dapat kita pahami bahwa kegiatan mediasi ini dapat membuat sebuah kesepakatan damai anatara para pihak. Sedangkan Takdir Rahmadi menjelaskan bahwa mediasi merupakan sebuah proses didalam penyelesaian yang berkaitan dengan sengketa antara para pihak atau lebih melalui sebuah jalur perundingan yang menghasilkan kata mufakat dengan bantuan dari para pihak-pihak yang netral dan tidak memiliki kewenangan untuk dapat memutus, yang mana dikenal dengan istilah mediator. ${ }^{10}$ Rahmadi Usman menjelaskan pula bahwa mediasi adalah sebuah penyelesaiansengketa dengan cara menengahi perkara dan orang yang menengahi perkara tersebut dikenal dengan mediator. ${ }^{11}$ Berdasarkan pada pendapat ahli diatas maka penulis mengartikan bahwa mediasi adalah sebuah proses dengan cara perundingan yang mana mediator memiliki sertifikat mediator yang diakui dan dikeluarkan oleh Mahkamah Agung maupun lembaga yang tela memperoleh akreditasi dari Mahkamah Agung yang meana menyetakan seseorang tersebut telah lulus pelatihan dan sertifikat mediasi.

Keberadaan dari sebuah lembaga mediasi merupakan salah satu bentuk dari APS Medis, yang diatur secara tegas didalam Pasal 29 Undang-Undang Kesehatan yang menyebutka bahwa berkaitan dengan tenaga kesehatan yang mana diduga melakukan sebuah kelalaian didalam menjalankan seuah profesi, terjadinya kelalaian ini harus dilakuan penyelesaian lebih dulu melalui lembaga mediasi. Yang mana berkaitan dengan penjelasan mediasi tersebut menjelaskan mengenai alasan dan tujuan dilakukannya sebuat mediasi, yaitu bahwa mediasi dapat dilakukan apabila muncul sebuah sengketa antara pasien dengan tenaga kesehatan. Mediasi ini dilakukan dengan adanya sebuah tujuan bahwa untuk menyeleseikan sebuah sengketa di luar ranag peradilan yang sudah barang tentu dilakukan oleh lembaga mediator yang sudah bersertifikat dan diakui oleh Mahkamah Agung.

Pada Undang-Undang Rumah Sakit tidak ada menyebutkan secara konkrit mengenai lembaga yang melakukan penyelesaian terhadap sengketa medis, tetapi didalam Pasal 60 mengatur mengenai Pengawas Rumah Sakit Provinsi (BPRS Provinsi), yang mana peran dari lembaga ini adalah untuk dapat melakukan upaya pemyelesaian sengketa melalui jalur mediasi. Maka sengketa medis yang terjadi di rumah sakit harus dapat diupayakan melalui jalur mediasi, hal tersebut berdasarkan bahwa sebagian sengketa pada rumah sakit sebagai sebuah institusi peyelenggara pelayanan kesehatan dan dokter yang mengalami gugatan tersebut.

Pasal 1 angka 10 Undang-Undang Perlindungan Konsumen pun menggariskan bahwa APS merupakan sebuah lembaga didalam melakukan penyelesaian terhadap prosedur yang sudah disepakati oleh para pihak, yaitu melalukan diluar pengadilan melalui cara negoisasi, mediasi, konsltasi, konsiliasi dan penilaian ahli. Pasal 5 ayat (1) dan (2) Undang-Undang AAPS memberikan penjelasan bahwa lembaga arbitrase merupakan sebuah lembaga yang mana ditetapkan sebagai lembaga yang melakukan sebuah penyelesaian dari terjadinya perkara maupun hadirnya sebuah sengketa dan lembaga mediator ini memiliki sebuah tanggung jawab pada sebuah koridor yang lebih luas, yang berkaitan dengan seluruh perkara didalam sebuah sengketa bahkan berkaitan dengan terjadinya sebuah perbedaan dari sebuah pendapat didalam perkara hukum keperdataan, yang diselesaikan pada sebuah niat dan ihtikad dari pada para pihak berkaitan dengan upaya dari penyelesaiianya.

Melalui Perma Nomor 1 Tahun 2016 Tentang Prosedural Mediasi yang mana menjelaskan bahwa pengadilan tidak hanya memiliki tugas dan serta wewenang dalam hal pemeriksaan, mengadili serta menyelesaikan perkara yang diterimanya saja, namun memiliki sebuah wewenang untuk dapat membuat perdamaian kepada para pihak yang berperkara. Maka dengan adanya Perma tersebut berkaitan dengan waktu yang singkat didalam mediasi yang semula selama 40 hari menjadi 30 hari yang mana terhitung semenjak penetapan perintah didalam hal melakukan mediasi. Selanjutnya adanya sebuah kewajiban untuk para pihak (inperson) untuk dapat menghadiri secara langsung sebuah pertemuan mediasi tanpa atau dengan didampingi oleh kuasa hukum, namun apabila ada alasan lain seperti kesehatan yang kurang baik dan tidak memingkinkan untuk hadir pada mediasi dan didampingi oleh surat keterangan dari dokter, dibawah pengampuan, kediaman dan tempat tinggal di luar negeri maupun menjalankan sebuah tugas negara dan adanya sebuah tanggung jawab profesi maupun pekerjaan yang tidak dapat dikerjakan. Didalam Perma ini menegaskanbahwa seorang mediator memiliki peranan yang independen agar dapat berperan lebih aktif lagi pada penyelesaian perkara-perkara maupun sengketa di luar badan pengadilan, setelah itu hasil dari mediasi disepakati untuk dapat diajukan sebuah penetapan kepada pengadilan melalui sebuah mekanisme gugatan.

Keluarnya Perma tersebut sesungguhnya merupakan sebuah institusionalisasi dari proses mediasi kepada sebuah sistem peradilan, yang mana sebelum sebuah perkara dipersidangkan pada badan peradilan harus melalui proses mediasi terlebih dahulu sebagai sebuah upaya dari alternatif penyelesaian sengketa bagi para pihak yang

\footnotetext{
${ }^{9}$ Gatot Soenmartono, Arbitrase dan Mediasi Indonesia, PT.Gramedia Pustaka Utama, Jakarta, 2015, hlm. 119.

${ }^{10}$ Takdir Rahmadi, Mediasi Penyelesaian Sengketa Melalui Pendekatan Mufakat, Rajawali Pers, Jakarta, 2015 , hlm. 12.

${ }^{11}$ Rahmadi Usman, Pilihan Penyelesaian Sengketa di Luar Pengadila, PT.Citra Aditya Bakti, Bandung, 2013 , hlm. 79.
} 
bersengketa. Namun harus dipahami bahwa dalam Pasal 4 menjelaskan bahwa semestinya semua perkara tanpa terkecuali harus melalui tahapan mediasi baik dihadiri oleh kedua belah pihak maupun hanya di hadirioleh salah satu pihak saja. ${ }^{12}$ Melalui sebuah cara mediasi hal ini lebih berdayaguna sebab dari awal mediator sudah bertindak secara proaktif akan menghubungi para pihak yang berperkara agar berdamai.

Tujuan dari mediasi adalah untuk dapat menyelesaikan sengketa dengan memberikan win-win solution dan dalam hal ini pastilah memberikan dampak/efek hukum yang baik bagi para pihak yang berperkara, karena hasil mediasi adalah hasil dari kesepakatan dari para pihak dan hal ini adalah baik bagi para pihak karena atas kesepakatan bersama. Dengan adanya mediasi yang disepakati oleh para pihak yang bersengketa terhadap penyelesaian perkara menjadi sangat kuat, sebab kemungkinan menjadi lebih kecil untuk naik pada tingkat peradilan dan pada akhirnya memberikan sebiah dampak yang positif bagi para pihak dan juga pengadila karena tidak terjadi penumpukan perkara dalam peradilan.

\section{Kriteria/Bentuk Sengketa Medis yang Dapat Diselesaikan Melalui Lembaga Mediasi}

Pasal 29 Undang-Undang Kesehatan dan Pasal 60 Undang-Undang Rumah Sakit merupakan sebuah dasar yuridis mengenai sebuah dasar dari sebuah lembaga mediasi. Sebab prinsip dadar dari mediasi adalah merupakan salah satu bentuk alternative didalam penyelesaian sebuah sengketa diluar pengadilan serta belum sampai pada pokokpokok perkara kedalam badan peradilan. Dikarenakan belum adanya pengaturan secara khusus mengenai eksistensi lembaga mediasi dalam hal sengketa medis maka dasar yang di atur didalam Undang-Undang AAPS dan Perma tersebut masih sangatlah relevan sebagai sebuah landasan yuridis sebagai penentuan sebiah kriteria dalam hal sengketa medis yang mampu diselesaikan melalui jalur mediasi.

Pasal 6 ayat (1) Undang-Undang AAPS menyebutkan sevara jelas bahwa "sengketa atau beda pendapat perdata dapat diselesaikan oleh para pihak melalui alternatif penyelesaian sengketa (termasuk di dalamnya mediasi) yang didasarkan pada itikad baik dengan mengesampingkan penyelesaian secara litigasi di Pengadilan Negeri. Pasal tersebut dapat kita jadikan sebagai sebuah dasar yuridis didalam hal menentukan sebuah kriteria pada sengketa medis yang dapat diselesaikan melalui sebuah jalur mediasi yang tidak termasuk kedalam bagian Hukum Pidana, maka harus dilakukan terlebih dahulu mengenai mana saja yang termasuk wilayah Hukum Perdata pada sebuah sengketa medis yang berdasarkan pada Pasal 29 Undang-Undang Kesehatan.

Maka apabila tenaga kesehatan dinilai melakukan sebuah kelalaian didalam tindakannya hal ini harus dilakukan penyelesaian melalui jalur mediasi. Maka makna dari kelalaian yang merujuk kedalam sebaimana yang terdapat di dalam Undang-Undang AAPS haruslah dipandang sebagai lapangan Hukum Perdata serta berdasarkan pada ketentuan dari Pasal 1365 dan 1366 Kitab Undang-Undang Hukum Perdata berkaitan dengan tindakan melawan hukum. Untuk dapat menentukan ada atau tidaknya sebuah unsur kelalaian yang dilakukan oleh tenaga medis maupun dokter harus dapat dilakukan pembuktian yang mana terdiri dari:

1. Terjadinya sebuah perbuatan, yang terjadinya hubungan terapeutik antara dokter dan juga pasien dibuktikan dengan rekam medis serta informet convet,

2. Terjadinya sebuah tindakan yang melanggar hukum, yang tertuanh didalam sebuah hubungan terapeutik,

3. Terdapat sebuah kesalahan yang berupa kelalaian maupun kekurang hati-hatian yang dimulai dengan tindakan medis/dokter,

4. Timbulnya kerugian kepada pasien,

5. Adanya kausal dari sebuah perbuatan dari doktek/medis dengan adanya kerugian yang diterima oleh pasien.

Rumah Sakit sebagai sebuah institusi yang mana mewadahi dari bekerjannya dokter/medis pada melakukan sebuah praktek, maka apabila terjadi kelalaian maka dapatlah diberlakukan Pasal 1367 sebagai sebuah landasar terhadap pemberlakuan Pasal 46 Undang-Undang Rumah Sakit berkaitan dengan sebuah pertanggungjawaban pihak Rumah Sakit atas sebuah kesalahan/kelalaian yang dilakukan oleh dokter ataupun pihak rumah sakit. Apabila adanya kesalahan, kelalian maupun kekuranghatian yang timbul akibat tindakan dokter maupun medis akan timbul masalah, yaitu kesulitan didalam membuktikan tindakan tersebut hal ini dikarenakan adanya Standar Operasional Prosedur (SOP) sebuah tindakan dari sebuah tindakan profesi medis, SOP pelayanan rumah sakit maupun kedisiplinan dari seorang dokter. Maka dalam hal ini sangat diperlukan sebuah peranan dari MKDKI yang merupakan sebuah lembaga medis yang dapat menentukan sebuah kelalaian, kesalahan dan kekurang-hati-hatian dari apa yang terjadi.

Tindakan yang berkaitan mengenai fungsi dan wewenang dari MKDKI ini sesuai dengan yang telah ditetapkn didalam Undang-Undang Praktek Kedokteran, yang memiliki wewenang didalam penegakan disiplin bagi dokter dan juga dokter gigi serta bukan untuk mencari pelanggaram dalam hal pelanggaran etika. Undang-Undang Kedokteranpun menjelaskan mengenai apabila terdapat orang yang dirugikan maka orang/pasien tersebut dapat mengajukan sebuah pengaduan kepada lembaga tersebut. Agar terciptanya sebuat penegakan disiplin didalam

12 Siddiki, Mediasi di Pengadilan Hak Asasi Peradilan Sederhana, Cepat dan Biaya Ringan, 2017, diakses pada https://badilag.mahkamahagung.go.id/, diakses pada tanggal 21 Maret 2021. 
mewujudkan peraturan yang baik guna pelaksanaan sebuah pelayanan yang baik. Adapun yang termasuk kedalam pelanggaran disiplin menurut MDKDKI adalah sebagai berikut:

1. Terdapat ketidak kompetenan dari sebuah praktek dokter;

2. Tidak memberikan rujukan pasien kepada dokter gigi lainnya yang memiliki kemampuan maupun kompetisi sesuai/lebih tinggi;

3. Memberikan pekerjaan kepada tenaga kesehatan yang tidak memiliki kemampuan didalam melaksanakan tigas tersebut;

4. Memberikan amanat kepada dokter maupun dokter gigi pengganti yang mana tidak memiliki wewenang dan kompetisi yang memadai;

5. Kondisi kesehatan yang tidak mendukung, baik fisik maupun mental saat melaksanakan praktek/tindakan;

6. Melakukan apa yang seharusnya tidak perlu dilakukan sesuai dengan pertanggungjawaban terhadap profesinya, yang dapat membahayakan pasien;

7. Tindakan pengobatan dan pemeriksaan yang berlebih;

8. Tidak adanya keterbukaan terhadap informasi yang jujur serta etis kepada keluarga pasien dan pasien dalam melaksanakan praktek;

9. Tindakan yang dilakukan tanpa adanya persetujuan dari pasien maupun keluarga dekat dalam sebuah tindakan;

10.Dilakukan secara sengaja tidak membuat rekam medic serta menyimpannya, yang mana hal ini telah diatur didalam perundang-undangan yang berlaku serta etika profesi; dan

11.Terjadinya sebuah tindakan yang dapat memberhentikan sebuah kehamilan. ${ }^{13}$

Sesungguhnya MKDKI bukanlah sebiah lembaga yang memberikan sebuah persidangan, sebab hal ini tidak akan terlepas dari adanya kesepakatan dan lain sebagainya, sebab yang diberikan sebuah keputusan berkaitan dengan adanya sebuah pelanggaran dari tindakan disiplin dari para dokter maupun dokter gigi yang dilakukan sebuah oengaduan kepada lembaga tersebut. Bila terjadi pembuktian dan hal tersebut memang terbukti maka lembaga ini dapat memberikan sebuah sanksi disiplin dapat berupa memberikan peringatan, memebrikan rekomendasi pencabutan Surat Tanda Registrasi (STR) maupun surat izin praktek (SIP) serta lembaga ini seharusnya menjadi lembaga rujukan didalam hal melakukan mediasi dalam hal sengketa medis yang terjadi. Namun sebuah kendala yang timbul adalah lembaga ini hanya ada di Ibu Kota Negara, yang mana hal ini memberikan kesulitan kepada para pasien serta pihak keluarga didalam melakukan pengaduan terhadap adanya pelanggaran disiplin yang dilakukan.

Lainhal nya apabila tidak terdapat unsur pidana, sebagai mana yang diatur dalam Kitap Unddang-Undang Hukum Pidana (KUHP), Undang-Undang Kesehatan serya Undang-Undang Kedokteran. Pada kondisi seperti ini pasien berada dalam kondisi yang komplek sebab pembuktian dari pelanggaran ini berada pada tingkat penyidikan yang dilakukan oleh pihak Kepolisian dan Kejaksaan. Terdapat beberapa ketentuan berkaitan dengan suatu tindakan medis yang di atur didalam KUHP seperti yang terdapat didalam Pasal 333, 346, Pasal 347 jo.Pasal 194 UndangUndang Kesehatan yang mana hal ini berkaitan dengan tindakan aborsi tidak atas indikasi medis dan lain sebagainya.

Sebuah sengketa medis yang dapat dilakukan sebuah penyelesaian melalui lembaga mediasi merupakan sengketa yang masuk dalam ranah Hukum Perdata dan jelas bukan masuk kedalam ranah Hukum Publik, yang mana diperlukan sebuah persyaratan utama yang timbuk akibat hubungan keperdataan antara para pihak, pada hal ini berupa sebuah hubungan terapeutik antara dokter dan pasien dan hal yang utama adalah tidak terdapatnya sebuah unsur pidana didalam pembuktian keperdataan tersebut. Namun harus dipahami pula oleh pasien bahwa dari setiap tindakan medis pasti menimbulkan sebuah kemungkinan berupa resiko medis. Terjadinya sebuah kondisi overmacht ini harusnya dapat disikapi dengan adanya keterbukaan terhadap informasi publik yang bersumber dari dokter dan rumah sakit.

\section{Kekuatan Hukum Putusan Lembaga Mediasi Pada Penyelesaian Sengketa Medis}

Buah dari sebuah penyelesaian sengketa medis dengan melaui lembaga mediasi memiliki kekuatan hukum yang sama pula dengan hasil dari mediasi yang lainnya, sebagaimana yang terdapat didalam Perma Nomor 01 Tahun 2008 jo.Perma Nomor 01 Tahun 2016, maupun berdasarkan kepada Undang-Undang AAPS. Perma tersebut menjelaskan bahwa apabila dari sebuah mediasi menghasilkan sebuah kesepakatan, maka para pihak yang dibantu oleh mediator memiliki sebuah kewajiban untuk dapat merumuskan kesepakatan yang telah tecapai. Serta para pihak menandatangani dan setelah itu menghadap kembali kepada Hakim sesuai dengan hari persidangan yang tela disepakati untuk melakukan perdamaian dan hakim dapat mengukuhkan kesepakan tersebut didalam sebuah akta perdamaian.

Kekuatan hukum dari akta perdamaian tersebut sifat hukum nya adalah mengikat kepada kedua belah pihak dan akta ini bersifat final dan tidak lagi memungkinkan timbul upaya lain dalam hal melanjutkan pada jalur litigasi.

${ }^{13}$ Buku Perhimpunan MKDKI Tahun 2018. 
Namun apabila terjadinya penyelesaian sebuah sengketa secara non litigasi maka hasil dari kesepakatan tersebut harus dilakuan penuangan terhadap akta tertulis yang pastinya kekuatan hukum yang mengikat sebagai perjanjian yang mengikat para pihak. Bila salah satu pihak tidak melakukan kewajibannya sebagaimana yang tercantum didalam akta kesepakatan yang telah di tanda tangani, maka pihak satunya dapat pula melakukan gugatan melalui jalur litigasi dengan gugatan wanprestasi berlandaskan pada Pasal 1234 KUHPer serta akta yang telah ditanda tangani sebelumnya dijadikan sebagai barang bukti pada proses peradilan dan hasil mediasi sebelumnya tidak dapat dilakukan upaya banding sebagaimana yang telah jelas diatur didalam Undang-Undang AAPS. Berkaitan dengan Banding terdapat didalam Pasal 6 ayat (7), dan Pasal 25 ayat (1) dan (2) Perma menentukan bahwa materi dalam hal perundingan mediasi tidak memiliki batasan pada petitum gugatan dan posita.

Apabila mediasi mancapai kata sepakat yang dibantu noleh mediator maka ada sebuah kewajiban untuk dapat melakukan sebuah perumusan kesepakatan secara tertulis dan harus ditandatangani oleh para pihak serta mediator. Berkaitan dengan timbulkan hubungan terapeutik, yang berkaitan dengan dokumen penting adalah sebuahh dokumen informed concernt serta rekam medisyang mana menjadi sebuah latar belakang lahirnya sebuah hubungan hukumdan lazim disebut dengan hubungan terapeutik. Maka hal ini perlu diperhatikan oleh para dokter/dokter gigi untuk selalu mengiatamakan kedua dokumen ini karena dua dokumen tersebut bias menjadi alat bukti yang sangat kuat terhadap tindakan medis yang dilakukan.

\section{SIMPULAN}

Tidak adanya penjelasan secara eksplisit mengenai penyelesaian sengketa medis melalui lembaga mediasi, sehingga menimbulkan berbagai penafsiran bahwa sengketa medis dapat diselesaikan melalui jalur sengketa alternative khususnya melalui cara mediasi dengan kriteria bahwa tidak terdapat unsur pidana didalamnya. Maka permasalahan mediasi terkait dengan tindakan medis diselesaikan berdasarkan pada Perma dan Undang-Undang AAPS. Kesepakatan terhadap penyelesaian sengketa yang di akibatkan adanya perbedaan pendapat selanjutnya apabila terdapat kesepakatan dari para pihak yang bersengketa maka ksepakatan tersebut dapat dituangkan pada sebuah akta yang tertulis, yang bersifat final dilakuan dengan sebuah itikad yang baik, maka wajib didaftarkan pada Pengadilan Negeri dengan mengajukan sebuah gugatan dan pengukuhan dalam sebuah akta perdamaian oleh Hakim Pengadilan setempat.

\section{Saran}

Sebaiknya dilakukan pembentukan sebuah lembaga Komite Mediasi pada semua rumah sakit, untuk dapat menyelesaikan sengketa medis yang terjadi dan dilakukan pengawasan serta pembinaan oleh Badan Pengawas Rumah Sakit Provinsi yang berdasarkan pada Undang-Undang Rumah Sakit serta dibentuknya lembaga MKDKI Tingkat Provinsi yang profesionald an tidak memihak yang memberikan kepastian hukum bagi pihak-pihal yang bersengketa.

\section{DAFTAR PUSTAKA \\ Buku}

Buku Perhimpunan MKDKI Tahun 2018.

Gatot Soenmartono. 2015. Arbitrase dan Mediasi Indonesia. PT.Gramedia Pustaka Utama. Jakarta.

Rahmadi Usman. 2013. Pilihan Penyelesaian Sengketa di Luar Pengadila. PT.Citra Aditya Bakti. Bandung.

Soerjono Soekamto. 2006. Pengantar Penelitian Hukum. Universitas Indonesia. Jakarta.

Takdir Rahmadi. 2015. Mediasi Penyelesaian Sengketa Melalui Pendekatan Mufakat. Rajawali Pers. Jakarta.

Titon Slamaet Kurnia. 2007. Hak-Hak Atas Derajat Kesehatan Optimalisasi Sebagai HAM di Indonesia. Alumni. Bandung.

\section{Internet}

Siddiki. Mediasi di Pengadilan Hak Asasi Peradilan Sederhana, Cepat dan Biaya Ringan. 2017, diakses pada https://badilag.mahkamahagung.go.id/.

\section{Undang-Undang}

Undang-Undang Dasar Negara Republik Indonesia Tahun 1945.

Undang-Undang Nomor 8 Tahun 1999 Tentang Perlindungan Konsumen.

Undang-Undang Nomor 29 Tahun 2004 Tentang Kedokteran.

Undang-Undang Nomor 25 Tahun 2009 Tentang Pelayanan Publik.

Undang-Undang Nomor 36 Tahun 2009 Tentang Kesehatan.

Perma Nomor 1 Tahun 2016 Tentang Prosedural Mediasi.

Peraturan Menteri Kesehatan Republik Indonesia Nomor 150/MENKES/PER///2011 Tentang Keanggotaan Majelis Kehormatan Disiplin kedoteran Indonesia. 